\title{
ДО ПИТАННЯ ПРО ПРИЙОМИ НЕЙТРАЛІЗАЦІї МІЖОСОБИСТІСНИХ КОНФЛІКТІВ
}

\begin{abstract}
У статті представлено теоретичне узагальнення методів нейтралізації міжособистісного конфлікту для реалізаиії механізмів, щзо вможливлюють конструктивне завершення суперечки. Метою наукової роботи $\epsilon$ характеристика прийомів нейтралізаиії МК, які в основному не залежать від сфери людської діяльності. Нейтралізачія конфліктів розглядається як комунікативна ситуаџія, коли один із суб'єктів намагається подолати складні обставини, послабити видимі суперечності, схилити співрозмовника до своєї точки зору або/та досягти компромісу. Основна увага приділяється словесній поведіниі людини, яка хоче подолати потенційні або реальні розбіжності. Беручи до уваги теоретичні досягнення М. Дойча, В. Лінкольна, М. Розенберга, висновуємо, щио такі методи та прийоми повинні насамперед ураховувати кілька важливих чинників: модель конфлікту (структурну чи процесуальну); фактори (інформаційні, структурні, иіннісні, стосункові, поведінкові); тип (відповідно до потреб людини, типу суперечностей, інтенсивності, часу розвитку протидіi); тип комунікативних перешкод (лінгвістичні, психологічні, когнітивні, соціальні, фізичні); наявність необхідних умов для нейтралізацїі (основних, щчо формують $і$ забезпечують ефективність контакту, та індивідуальних); принципи спілкування (провокаційне чи ненасильницьке, останнє має своєю умовою розуміння почуттів, психічного стану іншої особи, спостережливість); права та обов 'язки сторін (передбачає планування та здійснення дій особи, яка бажає нейтралізувати конфлікт; взаєморозуміння фізичними особами прав та обов'язків один одного); тип конфліктності людини та стиль поведінки (самооиінка, бажання домінувати, консерватизм мислення, прямолінійність, тривожність тощо); вік, стать опонентів. Також визначено, щчо для успіху взаємодї індивідів важливими $\epsilon$ їхні особисті вербальні риси, які визначаються національними властивостями, нормами, специифікою реалізації мовної тактики.
\end{abstract}

Ключові слова: міжособистісний конфлікт, мовна поведінка особи, прийоми нейтралізачї конфлікту, сфера розвитку конфлікту.

Liudmyla BILOKONENKO, orcid.org/0000-0001-9329-1852 Doctor of Philological Sciences, Associate Professor at the Department of Ukrainian Language Kryvyi Rig State Pedagogical University (Kryvyi Rig, Dnipropetrovsk region, Ukraine) lessons1020@gmail.com

\section{TO THE QUESTION OF METHODS OF NEUTRALIZING INTERPERSONAL CONFLICTS}

The article presents a theoretical generalization of methods of neutralizing interpersonal conflict for the practical implementation of mechanisms that allow effective completion of the dispute, regardless of the scope. The purpose of scientific work is to characterize the techniques of neutralization of IC, which are mainly independent of the field of human activity. Conflict neutralization is seen as a communicative situation where one of the subjects tries to overcome challenging circumstances, weaken the appearance of contradictions, incline the interlocutor to his point of view or reach a compromise. The focus is on the verbal behaviour of a person who wants to overcome potential or real contradictions. Taking into account the theoretical achievements of M. Deutsch, V. Lincoln, M. Rosenberg, it is concluded that such tools must, first of all, take into account: the model of conflict (structural or procedural); factors (information, structural, value, relationship, behavioural); type (according to human needs, type of contradictions, intensity, time of development of counteraction); type of communication obstacles (linguistic, psychological, cognitive, social, physical); availability of the necessary conditions for neutralization (basic, forming and ensuring the effectiveness of contact, and individual); principles of communication (provocative or nonviolent communication, the latter having the condition of empathy, observation, feelings, request); the rights and obligations of the parties (involves the planning and implementation of actions of a person who wishes to neutralize the conflict; mutual understanding of the rights and obligations of each 
other by the individuals); type of conflict person and style of his behaviour (self-esteem, desire to dominate, conservatism of thinking, straightforwardness, anxiety, etc.); age, gender, etc. features of opponents. Also crucial for the success of this mechanism are the personal verbal traits of the individual, which are determined by the national properties, norms, specificity of implementation of language tactics.

Key words: interpersonal conflict, linguistic behaviour of a person, methods of conflict neutralization, a sphere of conflict development.

Постановка проблеми. Мова фокусує в собі властивості, типові для поведінки суб'єкта в етнолінгвокультурному середовищі в певних ситуаціях. Завдання дослідника полягає в тому, щоб виявити ці ознаки, дати їм соціо- та психолінгвістичну інтерпретацію, показати, що вони $є$ реалізацією мовних уподобань спільноти. Серед значущих соціально-психологічних явищ - надзвичайно різноплановий об'єкт - мовний міжособистісний конфлікт (далі-МК), а також механізми його подолання. Нейтралізація суперечки - ситуація, коли особа намагається змінити іiі розвиток, досягти взаєморозуміння. Тож розширити поле дослідження МК можна завдяки зверненню до питання про прийоми його нейтралізації в процесі комунікації, способів взаємного пристосування або адаптації, коли хоча б один з опонентів намагається «обійти» перешкоду. Такий ракурс зумовлює актуальність нашого дослідження.

Аналіз досліджень. Роки незалежності України відкрили шлях до розвитку конфліктології, внаслідок цього у вітчизняній науковій царині кінця XX - поч. XX ст. відбулися зрушення, що засвідчили зацікавлення МК. Вивченню певних аспектів МК присвячено чимало праць, уможлививши його розгляд у сфері перетину лінгвістики із психологією (Грищук, 2011), соціологією (Даниленко, 2006; Козер, 1992), педагогікою (Антонов, 2005) тощо. Серед наукового доробку за останні роки бачимо й праці, в яких порушене питання про способи (прийоми, чинники, умови) розв'язання (урегулювання, вирішення, профілактики, подолання, запобігання) МК, зокрема, в психології (Варлакова, 2011; Коберник, 2010), педагогіці (Козич, 2008), сфері управління (Довгань, 2006) тощо. До невирішеної раніше частини загальної проблеми нейтралізації МК, якій і присвячується ця стаття, є питання про універсальну систему механізмів, що дають змогу подолати конфліктні форми поведінки осіб незалежно від сфери перебігу. Новизна матеріалу полягає в уточненні теоретичних уявлень про зміст загальної системи чинників, які вможливлюють оптимальні поведінкові тактики для завершення МК.

Метою статті $\epsilon$ характеристика прийомів нейтралізації МК, що переважно не залежать від області діяльності людини.
Виклад основного матеріалу. Нейтралізація МК - це ситуація, коли один із суб'єктів намагається подолати складні обставини, послабити вияв суперечностей, схилити співрозмовника до своєї точки зору або досягти компромісу. В основі процесу - універсальні риси поведінки індивіда, зумовлені національними ознаками, особливостями мовного етикету, нормами поведінки, специфікою реалізації комунікативних тактик. Тож $\epsilon$ потреба зосередити увагу на вербальній поведінці людини, яка хоче перебороти потенційні або реальні суперечності.

Перерахувати всі прийоми подолання МК неможливо, але важливим кроком до аналізу цього механізму є положення про нові перспективи в роботі з конфліктами, які сформулював М. Дойч (Deutsch, 1985: 72-73):

1. Помилкове сприйняття МК лише як процесу виграшу/втрат. Насправді лише частина конфліктів $є$ такими. Тому є потреба розвивати технології, які вможливлюють усвідомлення спільних цілей, навіть попри протилежні інтереси.

2. Якщо МК не є конфліктом виграшу/втрат, необхідно підтримувати кооперативну орієнтацію індивідів, яка повинна фокусуватися на інтересах сторін і стимулювати пошук рішення, яке відповідає їхнім законним прагненням.

3. Повний, відкритий, взаємно шанобливий комунікативний процес повинен бути інтенсифікований так, щоб сторони могли чітко висловлюватися та тематично розуміти інтереси один одного. Цей процес зменшить помилки в розумінні, які спричиняють захисні дії індивідів. Соціальна психологія розвиває технології стимулювання успішного комунікативного процесу.

4. Розвиток широкого діапазону вибору для розв'язання питання, в якому різняться інтересів конфліктантів. $€$ техніки, що допомагають людям розширити новизну альтернативних можливостей для цього.

5. Глибоке усвідомлення правил, тактик, зовнішніх ресурсів і засобів, які унеможливлюють нечесні прийоми та «експлуатацію» опонента. Тут потенційно корисною $є$ «третя сторона» - радник, медіатор, арбітр.

Проте у своїх працях М. Дойч визначає лише два способи виходу з конфлікту: кооперативний 
(ураховуються й мінімізуються розбіжності) та конкурентний (підкреслюється різниця інтересів опонентів). Це означає, що подолання суперечностей не обов' язково супроводжене конструктивізмом, проте їхню причину все ж треба усунути. Тож відповідь на питання про прийоми нейтралізації конфлікту треба шукати, зважаючи на:

1. Модель МК - структурна чи процесуальна. У структурній моделі акцентовано умови, в яких відбувається перебіг конфлікту, та які визначають його динаміку. Це впливає на ситуацію завершення: деструктивна чи конструктивна, остання передбачає зміну обставин задля розв'язання проблеми. У процесуальній моделі важливим $€$ «рух», а не результат суперечки. Сторони концентруються на умовах перебігу конфлікту, тоді як варіанти завершення не мають значення.

2. Фактори МК. Це рушійні сили конфліктної взаємодії, що визначають його характер і риси (описані в американській конфліктології (Линкольн та ін., 1998):

а) інформація, яка є значущою для однієї сторони та неприйнятною для іншої. У такому разі сторони (сторона) мають неповні чи неточні факти, старі проблеми зі своєю «історією», зважають на чутки, дезінформовані один одним або «третьою стороною», умисно чи випадково приховували щось, або навпаки - небажано оприлюднили інформацію, неправильно інтерпретували слова, дії іншої людини або помилково декодували мовні засоби опонента. Складно нейтралізувати конфлікт, якщо певна інформація для суб'єкта є надзвичайно важливою, але його правом на неї нехтують. Утрачається або/та спотворюється інформація й через те, що люди сприймають її вибірково, тому що мають різні ціннісні та поведінкові пріоритети, світогляд, життєвий досвід тощо. Або індивід не озвучує інформацію через обмеженість слів, яким володіє, тому подолання МК передбачає збагачення словникового запасу. Значна кількість інформації втрачається через брак часу для спілкування: активне, насичене життя мінімізує його. Для соціальної перцепції необхідно присвятити час співрозмовнику. Деяка суттєва інформація на рівні підсвідомого словами не репрезентується, тож ії частково треба представляти невербальними засобами. Багато індивід не засвоює, оскільки уважно не слухає чи відволікається, думаючи про своє, тому є потреба повторювати, наголошувати, підкреслювати. Не всі повідомлення можуть бути зрозумілими, тому інформувати варто з урахуванням розумових здібностей, освіти, досвіду особи. Ту саму інформацію люди сприймають не однаково через різне знання певної проблеми; б) структурні фактори зумовлені формальною та неформальною організацією соціальної групи. Передбачають: владу, систему комунікації, соціальні норми, правосуддя, релігію, статус опонентів, традиції, ресурси, стандарти поведінки, час тощо. Тому припинення конфліктів передбачає уникнення політичних, релігійних, правових, міжнаціональних тем у контакті. Також багатьох проблем можна позбутися за умови відмови від дій заради власної вигоди та провокацій, розуміння їх наслідків. Насамперед має бути орієнтація на співробітництво або компроміс, аналіз можливих конфліктних ситуацій, визнання чужих інтересів;

в) ціннісні чинники - це принципи, яких свідомо дотримуються або якими нехтують. Сторони конфлікту один від одного очікують дій відповідно до норм, які вможливлюють порядок у соціумі, але так стається далеко не завжди. Цінності $є$ різні, а саме: особистісні й групові вподобання в поведінці, система поведінки всього суспільства, загальні нормативні та професійні; ідеологічні, системи переконань та пов'язані з ними очікування, терпимість, відхід в особливих обставинах, ставлення до змін тощо. Суспільство нерідко нав'язує загальні цінності, їх добровільно сприймають не всі, тож вони можуть об'єднувати або роз'єднувати людей. У такому разі переборення конфліктів спирається на вимушену загальносуспільну згоду. У профілактиці суперечок важливою також є зміна ціннісних орієнтацій для підвищення рівня поваги, довіри до вподобань іншого, боротьби з нетерпимістю до чужих думок. Різні верстви суспільства мають не однаковий статус, тому групи можуть боротися за власні цінності (напр., нові релігійні рухи, діяльність сексуальних або національних меншин). Ці процеси зумовлюють глибокі соціальні зміни з переоцінкою цінностей, формуванням їхньої нової системи. Тому для подолання суперечностей потрібна самосвідомість цивілізації. Якщо цінності епох та народів заявляють своє право на універсальність, то вони апріорі повинні об'єднувати людей;

г) фактор взаємовідносин - це задоволення чи незадоволення від контакту з іншою особою (особами). Важливими є: добровільні або примусові відносини та їхня сутність, важливість, цінність i тривалість; сумісність сторін у пріоритетах, поведінці, цілях; баланс сил; відмінності в освіті, життєвому досвіді; рівень довіри й авторитетності. Припинення деструктивного спілкування передбачає дії, що виключають виникнення самої проблемної ситуації чи усунення ії причин, джерел, які не допускають формування конфліктної свідомості людини. У цьому разі суб'єкт повинен володіти знаннями про методи своєчасного аналізу 
конфлікту, диференціювати підхід до різних індивідів. Точна діагностика значущих складників МК дає змогу легше знайти способи ефективної поведінки в ньому;

г) поведінкові фактори. У МК поведінка опонентів зачіпає систему їхніх поглядів, загрожує фізичній, фінансовій, емоційній, соціальній безпеці; викликає стрес, дискомфорт, знижує самооцінку, дратує, спричиняє негативні емоції, не виправдовує позитивних очікувань. Виникненню конфліктних дій може сприяти й низький рівень самосвідомості людини у сприйнятті різних життевих ситуацій. Підгрунтям для деструктивної поведінки є й неузгодженість між загальним уявленням суб'єкта про те, яким він повинен бути, та реальною самооцінкою. Тому переважно під час МК люди поводяться «неадекватно». Для подолання таких виявів $€$ певні методи: психологічні тренінги, індивідуально-психологічні консультації, аутотренінг, самоаналіз; загалом методи психокорекції.

3. Вид МК. Послаблення суперечностей залежить від того, які потреби людини не враховано, який тип суперечностей, наскільки вони гострі, яка тривалість події. Перебороти конфлікти можна, нейтралізувавши негативні наміри й емоції людей на основі аналізу мотивів їхньої поведінки, що унеможливить виникнення гострих $\mathrm{i}$ тривалих зіткнень. Такий метод не чудодійний, він передбачає систематичну, повсякденну роботу зі створення в суспільстві морально-психологічної атмосфери виключення причин конфліктів.

4. Сфера виникнення МК. Загальновизнаної класифікації немає, проте головно їх поділяють на політичні (розподіл владних повноважень, боротьба за владу), соціальні (суперечності інтересів соціальних спільнот та індивідів), економічні (боротьба за ресурси, розподіл власності, пільги, сфери економічного впливу), організаційні (різні цілі працівників, недоліки структур управління, незадовільна комунікація, умови оплати правці й т. ін.), сімейні (протиборство між членами сім’і, фінансові проблеми тощо), соціально-побутові (зіткнення груп або окремих індивідів із питань житла, користування побутовими послугами, розподілу обов'язків), педагогічні (у навчально-виховальному процесі). Оскільки сфери вияву різноманітні, універсального шляху для подолання немає. Для конфліктів різних рівнів взаємодії повинні бути різні прийоми нейтралізації.

5. Причиною МК $є$ певні типи перешкод:

a) лінгвістичні, поміж яких визнаємо: міжмовні, зумовлені різними мовами спілкування, коли виникає відчуття, що відсутність очікуваної реакції співрозмовника $є$ конфліктною пове- дінкою; фонетичні, спричинені дефектами чи особливостями (швидке/повільне, голосне/тихе) мовлення; семантичні, пов'язані з поняттями, які використовуються під час контакту (різне розуміння значень слів, незнання іншомовних лексем, жаргонів тощо), що виникають на грунті вікових, освітніх, культурних відмінностей; граматичні порушують структуру і зміст висловлень; логічні через несприйняття логіки та аргументів іншого;

б) психологічні - перешкоджають прийомупереданню інформації (особистісні риси, емоції, упереджене ставлення до співрозмовника і т. ін.);

в) когнітивні - передбачають своєрідність мислення суб'єкта та наявність у його свідомості мисленнєвих стереотипів;

г) соціальні - породжуються соціокультурними відмінностями людини, зумовлені ії приналежністю до певної мовної, етнічної, культурної, професійної спільноти, а також ії соціальною роллю, віком, статтю, фінансовим станом;

г) технічні, до яких зараховано фактори середовища, а саме: ознаки фізичних умов життя, що унеможливлюють комфорт у прийомі/переданні інформації;

д) фізичні: за умови порушення кордонів особистого простору в людини виникає образа, роздратування, обурення, агресія, навіть насилля. Подолати такі перешкоди можна. Для цього важливим $\epsilon$ виразне й розбірливе мовлення, володіння нормами літературної мови, врахування темпераментальної та когнітивної характеристики особи, акцентуація на соціокультурних рисах, мінімізація технічних проблем і дотримання особистих кордонів у стосунках.

6. Наявність необхідних умов для нейтралізаціï МК:

a) основні умови враховують організаційні механізми формування та забезпечення результативної інтерперсональної взаємодії членів соціуму, розвиток комунікативних контактів, досвід конструктивного завершення МК, психоемоційні ресурси для розв'язання проблем та систему компенсацій;

б) окремі умови зважають на міру близькості людей; офіційність (фіксовані, регульовані, унормовані) чи неофіційність (особисті, неформальні) взаємини людей; сприйняття особою іншої людини та їхніх стосунків: взаємно позитивні (пошук і досягнення результату в контакті), взаємно негативні (однозначність у неприйнятті співрозмовника, ворожість), односторонні позитивно-негативні (один із суб'єктів має негативну позицію щодо іншого, а останній налаштований налагодити контакт), односторонні суперечливо- 
позитивні або суперечливо-негативні стосунки, взаємно суперечливі чи взаємно байдужі контакти.

7. Принципи комунікації. Американський психолог М. Розенберг розробив принципи «ненасильницької комунікації» (Розенберг, 2018). Він описав три форми спілкування, які провокують непорозуміння та ускладнюють вихід із конфлікту: слова, які сприймають як вимогу, тому на них реагують підпорядкуванням або боротьбою; виражають осуд, тоді адресат думає погано про себе чи про адресанта; не залишають права на самостійність, на свою мету, свій шлях. А от ненасильницьке спілкування - спосіб налагодження стосунків, який передбачає емпатію до себе, до іншого та вираження самого себе. Ненасильницьке спілкування складається зі спостереження, почуття, прохання.

8. Права та обов'язки співрозмовників. Послаблення МК передбачає планування й реалізацію дій, які здійснює одна або обидві сторони. Значущим $€$ те, по-перше, в кого $є$ бажання нейтралізувати суперечність. За умови спрямованості на цей процес обох сторін, його результат буде максимально позитивним, та навпаки. По-друге, велике значення має взаємне розуміння індивідами прав та обов' язків один одного, уявлення про обопільні зобов'язання на основі загальноприйнятих норм. Навіть коли особи дотримуються визначених правил, вони в конфлікті не сприймають інтереси один одного; здатність, можливість опонента робити щось, користуватися чимось так, як він того хоче. Це означає, що людині відмовляють у праві на самостійно обрану поведінку. У Загальній декларації прав людини зазначено, що «Всі люди $<\ldots>$ повинні діяти щодо один до одного в дусі братерства» (стаття 1) та «Кожна людина має право на свободу переконань і на вільне їх виявлення; це право включає свободу безперешкодно дотримуватися своїх переконань та свободу шукати, одержувати і поширювати інформацію та ідеї <...> (Загальна декларація, 1948: стаття 19). Подолання суперечок передбачає дотримання цих принципів, готовність поважати права співрозмовника. Обов'язки - сумісна із правами категорія, оскільки вона забезпечує останні. Саме загальносоціальні обов'язки визначають потребу певної поведінки індивідів, яка не перешкоджала б розвитку суспільства. Тож визнання своїх обов'язків як людини і громадянина перед співгромадянами виключає чи мінімізує виникнення проблем та їхніх деструктивних наслідків.

9. Тип конфліктної особистості. У цьому питанні немає єдності, однак у конфліктології $\epsilon$ класифікація, відповідно до якої розрізняють демонстративний, ригідний, некерований, педантичний типи конфліктних особистостей (Смельянов, 2004: 90). Окрім цих типів, диференціюють інші: максималіст, який хоче мати все й одразу; песиміст, у спілкуванні з яким потрібне терпіння; дуаліст із його суперечностями у висловленнях i вчинках; нетерплячий, позиція якого несвідомо підштовхує до суперечки 3 ним; всезнайко, який будь-що знає краще за інших, тому нікого не чує, а лише говорить сам; базіка, він нетактовно втручається в розмову, любить поговорити про своє; а також «невинні брехуни», «помилкові альтруїсти», «старі діви» тощо. Така поведінка виникає як захисна реакція на певні життєві ситуації, спричиняє незручності й самим індивідам, і тим, хто з ними взаємодіє. Важливо розуміти: ці особи мають індивідуальні особливості, що впливають на процес перебігу та/або нейтралізації суперечок. Контакт із такими суб'єктами грунтований на прогнозуванні. На основі інформації про тип конфліктної особистості можна реагувати на випередження.

10. Вікові, гендерні особливості протиборчих сторін:

a) конфлікти поколінь складно однозначно схарактеризувати, як і їхні причини, оскільки перебіг зумовлений багатьма факторами. Суперечності поколінь нерідко починаються 3 незначних розбіжностей, які стають істотними протилежними тенденціями. Найбільш гостро така протидія відбувається між літніми людьми та молоддю. Проте конфлікти між поколіннями (рідних, близьких або зовсім незнайомих людей) мають і позитивні сторони: молодь головно прагне до розвитку, новацій; люди старшого віку зберігають та накопичують соціальний досвід. Профілактика конфліктів поколінь передбачає усунення причин, що викликають негативні наслідки, оптимізацію соціального захисту, формування моделі позитивного ставлення в суспільстві до різновікових осіб;

б) гендерні конфлікти: питання їхньої сутності теж $є$ актуальним. На жаль, у нашому суспільстві некомпетентні індивіди 3 гендерними забобонами ніяк не можуть звільнитися від ідеї андроцентризму, тому часто переживають суперечливі стани нереалізованих прагнень і очікувань. Один зі шляхів подолання МК такого типу - формування гендерної компетентності: знання про гендерну нерівність, уміння сприймати ситуацію гендерної нерівності та адекватно реагувати на неї та не демонструвати дискримінаційні гендерні змісти - це рух до засвоєння гендерних знань, умінь і способів коректної поведінки щодо людини іншої статі. 
Висновки. Попри те, що дослідники порушують питання про механізми подолання конфліктного протистояння осіб, головно акцентуються на цьому процесі в площині певної сфери перебігу (сімейна, виробнича, педагогічна, політична тощо). Ми вдалися до спроби уточнити структуру загальної системи прийомів, які вможливлюють нейтралізацію МК, незалежно від області діяльності людини. Частково врахувавши теоретичний доробок М. Дойча, В. Лінкольна, М. Розенберга, робимо висновок, що такі першорядно повинні враховувати модель, фактори та вид МК, типи комунікативних перешкод, умови подолання, принципи комунікації, права та обов'язки осіб, тип конфліктності людини; вікові, гендерні, соціорольові ознаки сторін. Для успішності цього механізму важливими $є$ особистісні риси вербальної поведінки індивіда, що зумовлені нашими національними рисами, мовним етикетом, нормами, специфікою реалізації комунікативних тактик. Запропонована інтерпретація засобів нейтралізації МК має не лише теоретичне значення, оскільки в перспективі вможливлює аналіз способів вербального впливу на мовця ще до початку конфліктної комунікації.

\section{СПИСОК ВИКОРИСТАНИХ ДЖЕРЕЛ}

1. Антонов Г. В. Педагогічні засади запобігання і розв'язання конфліктів у навчально-виховному середовищі вищого навчального закладу : дис. ... канд. пед. наук : 13.00.04. Харків, 2005. 198 с.

2. Варлакова Є. О. Формування готовності майбутніх практичних психологів до розв'язання міжособистісних конфліктів : автореф. дис. ... канд. психол. наук : 19.00.05. Київ, 2011. 18 с.

3. Грищук Е. Ю. Етнолінгвістична ідентичність як чинник регуляції міжособової взаємодії : дис. ... канд. психол. наук : 19.00.05. Київ, 2011. 339 с.

4. Даниленко О. А. Язык конфликта как объект лингвосоциологии. Социологические исследования. 2006. № 4. С. 89-98.

5. Довгань Н. П. Конфлікти в державному управлінні та шляхи їх вирішення : автореф. дис. ... канд. наук 3 держ. упр. : 25.00.01. Київ, 2006. 20 с.

6. Емельянов С. М. Практикум по конфликтологии. 2-е изд., доп. и перераб. Санкт-Петербург : Питер, 2004.400 с.

7. Загальна декларація прав людини : прийн. і прогол. резолюц. 217 А (III) Генеральної Асамблеї ООН від 10.12.1948 p. URL: https://zakon.rada.gov.ua/laws/show/995 015\#Text (дата звернення: 25.10.2020).

8. Козер Л. А. Завершение конфликта. Социальные и гуманитарные науки. Серия 11: Социология. 1992. № 4. С. $169-179$.

9. Козич I. В. Формування конфліктологічної компетентності соціального педагога в умовах магістратури : автореф. дис. ... канд. пед. наук : 13.00.05. Київ, 2008. 24 с.

10. Переговоры. Сокращенный вариант пособия для слушателей курса / У. Ф. Линкольн и др. Санкт-Петербург ; Рига : Эксперимент, 1998. 199 с.

11. Розенберг М. Ненасильственное общение. Язык жизни. Москва : Книжное издательство «София», 2018.288 с.

12. Deutsch M. Distributive Justice: A Social-Psychological Perspective. New Haven : Yale University Press, 1985.271 p.

\section{REFERENCES}

1. Antonov H. V. Pedahohichni zasady zapobihannia i rozviazannia konfliktiv u navchalno-vykhovnomu seredovyshchi vyshchoho navchalnoho zakladu [Pedagogical principles of conflict prevention and resolution in the educational environment of a higher educational institution] : dys. ... kand. ped. nauk : 13.00.04. Kharkiv, 2005. 198 s. [in Ukrainian].

2. Varlakova Ye. O. Formuvannia hotovnosti maibutnikh praktychnykh psykholohiv do rozviazannia mizhosobystisnykh konfliktiv [Formation of readiness of future practical psychologists to resolve interpersonal conflicts] : avtoref. dys. ... kand. psykhol. nauk : 19.00.05. Kyiv, 2011. 18 s. [in Ukrainian].

3. Hryshchuk E. Yu. Etnolinhvistychna identychnist yak chynnyk rehuliatsii mizhosobovoi vzaiemodii [Ethnolinguistic identity as a factor in the regulation of interpersonal interaction] : dys. ... kand. psykhol. nauk : 19.00.05. Kyiv, 2011. $339 \mathrm{~s}$. [in Ukrainian].

4. Danilenko O. A. Yazyik konflikta kak ob'ekt lingvosotsiologii [The language of conflict as an object of linguistic sociology]. Sociological research. 2006. № 4. S. 89 [in Russian].

5. Dovhan N. P. Konflikty v derzhavnomu upravlinni ta shliakhy yikh vyrishennia [Conflicts in public administration and ways to resolve them] : avtoref. dys. ... kand. nauk z derzh. upr. : 25.00.01. Kyiv, 2006. 20 s. [in Ukrainian].

6. Emelyanov S. M. Praktikum po konfliktologii [Workshop on conflict management]. Saint Petersburg : Peter, 2004. 400 s. [in Russian].

7. Zahalna deklaratsiia prav liudyny [Universal Declaration of Human Rights] : pryin. i prohol. rezoliuts. 217 A (III) Heneralnoi Asamblei OON vid 10.12.1948 r. URL: https://zakon.rada.gov.ua/laws/ show/995_015\#Text (data zvernennia: 25.10.2020) [in Ukrainian].

8. Kozer L. A. Zavershenie konflikta [Ending the conflict]. Social and Human Sciences. Episode 11: Sociology. 1992 . № 4. S. 169 [in Russian].

9. Kozych I. V. Formuvannia konfliktolohichnoi kompetentnosti sotsialnoho pedahoha v umovakh mahistratury [Formation of conflictological competence of a social pedagogue in the conditions of master's degree] : avtoref. dys. ... kand. ped. nauk : 13.00.05. Kyiv, 2008. 24 s. [in Ukrainian].

10. Linkoln U. F. i dr. Peregovoryi. Sokraschennyiy variant posobiya dlya slushateley kursa [Conversation. A shortened version of the manual for course participants]. SPb.; Riga : Experiment, 1998. 199 s. [in Russian].

11. Rozenberg M. Nenasilstvennoe obschenie. Yazyik zhizni [Nonviolent communication. The language of life]. M. : Book publishing house "Sofia", 2018. 288 s. [in Russian].

12. Deutsch M. Distributive Justice: A Social-Psychological Perspective. New Haven : Yale University Press, 1985.271 p 